\title{
Relationship Between Leadership Style with Service Quality
} Case Study: Food and Beverage Service Industry in Pagar Alam City

\author{
Samuel Hamonangan ${ }^{1}$, Pelliyezer Karo Karo ${ }^{2 *}$, Zulkifli Harahap ${ }^{3}$
}

\author{
1,2,3 Politeknik Pariwisata Palembang \\ *Corresponding author.Email: pelliyezer@poltekpar-palembang.ac.id
}

\begin{abstract}
This study links transformational and transactional leadership variables with service quality, this study measures the level of service performance of the quality of service provided to consumers. The study also analyzed how employees of the food and beverage service industry received between transformational leadership styles and transactional leadership styles, ultimately this research relationship between the indicator of service quality and leadership style. In managing service quality, a leadership style is needed that can encourage all service instruments to be carried out optimally. This study aims to analyze the relationship between the leadership style of restaurant managers in the city of Pagar Alam and the quality of service produced. Data were collected through questionnaire answers from 125 respondents and analyzed using correlation test. The results showed that transformational leadership style and transactional leadership style had a significant relationship with service quality, but the empathy dimension did not have a significant relationship with the dimensions of charisma and intellectual stimulation.
\end{abstract}

Keywords: leadership style, service quality, restaurant, city of Pagar Alam

\section{INTRODUCTION}

The Covid-19 pandemic that occurred in the period from 2019 to 2020 made the tourism industry a significant negative impact, based on a survey by the Central Statistics Agency (BPS) noting that the accommodation and food and beverage business sector experienced a decline of 92.47\% as of September 15, 2020 (katadata.co.id, accessed 1 November 2020), this impact was also experienced by the accommodation and food and beverage sector in South Sumatra Province which experienced year on year growth of only $7.56 \%$ in semester 12020 according to BPS data from South Sumatra published in August 2020. BPS catalog publication in Economic indicators in August 2020 recorded inflation of $0.13 \%$, the third-highest of nine sectors. This indicates that the food and beverage service industry sector nationally and locally is affected by the pandemic situation.

Pagar Alam City is one of the cities in the province of South Sumatra which was formed based on Law Number 8 of 2001 (State Gazette of the Republic of Indonesia Year 2001 Number 88, Supplement to the State Gazette of the Republic of Indonesia Number 4115), previously the city of Pagar Alam was included as an administrative city within the Lahat Regency. The city has an area of about $633.66 \mathrm{~km}^{2}$ with a population of 126,181 people and has a population density of around 199 people $/ \mathrm{km}^{2}$.

Every business in the food and beverage service sector must be innovative and creative to survive every industry that is engaged in a service industry must be able to meet the needs of its main consumers during a pandemic, both physically and 
psychologically. "Satisfaction is defined as pleasurable fulfillment. That is, the consumer senses that consumption fulfills some need, desire, goal, or so forth and this fulfillment is pleasurable" (Lau et al, 2005;49)[5]

In the process of recovering the service and beverage industry, before business actors carry out a strategy to bounce back from the pandemic period, a leadership style both transactional and transformational is needed to motivate the work ethic of their subordinates to provide good service in the $f \& b$ service industry, so that they can attract back. consumer trust.

\subsection{Service Quality}

(Kotler., 2000 (in Van Schalkwyk, 20011:190)[4] defines the notion of service "as an activity or benefit offered by the other groups in the form of something intangible. Intangible sense does not mean offering services only products, but also more appropriate to the delivery process". To control and assess services, a service quality instrument is needed to ensure the service process is by consumer expectations.

Service quality has become the basis for every organizational industry to develop and increase competitiveness by distinguishing the application of service quality provided to consumers, with the hope that industrial organizations can gain consumer trust better. This agrees with (Wilson et al., 2008 (in Van Schalkwyk, 2011:85)[11] "strategies that focus on customer satisfaction, high returns and service quality may be more successful than those that focus on cost-cutting only."

Providing service quality, in addition to being the character of a company, also the quality of service applied by the company cannot be imitated by similar companies, because service quality has characteristics that are difficult to imitate, besides maximizing service quality is also one way to attract customers to become customers. stay in a company.

Table 1. Variables of Service Quality

\begin{tabular}{|l|l|}
\hline No & \multicolumn{1}{|c|}{ Variables of Service Quality } \\
\hline 1. & Tangible \\
\hline 2. & Emphaty \\
\hline
\end{tabular}

\begin{tabular}{|l|l|}
\hline 3. & Reliability \\
\hline 4. & Responsiveness \\
\hline 5. & Assurance \\
\hline
\end{tabular}

Assurance is a dimension that describes the company's ability to foster trust of the customers through the friendliness and knowledge of staff in serving customers. Tangible is a dimension that describes everything physical in the service in influencing service quality. Empathy is a dimension that describes the attention of service providers to their customers. Responsiveness is a dimension that describes the form of responsive and timely action from service providers to customers. Reliability is a dimension that describes the ability of service providers to provide services accurately to customers. In the hospitality industry, reliability can be seen between the promotions carried out by hotel marketing and the reality of the services experienced, in this case, consumers can judge whether the reality in the field is reliable with the promotions carried out.

\subsection{Transactional Leadership}

In transactional leadership, leaders and followers exchange services to achieve their goals. This theory is based on contractual commitment in which the leader rewards his employees for achieving goals. It involves exchanges or transactions between leaders and followers such as agreements or rewards daily. The leader takes the initiative to make contact with his employees for exchange purposes. Through this exchange process, the needs of both the leader and the follower are met, but their goals are unrelated in the sense that they are not pursuing a common goal. So this theory assumes that employees will do their jobs effectively to achieve organizational goals based on exchanges, such as rewards.

"Transactional leadership can have a negative effect because constituents might feel that they are forced to do unpleasant tasks which could then negatively impact on quality performance". (Bass and Avolio., 1994 (in Van Schalkwyk, 2011:137)[2] 
“(a) Contingent Reward: Contracts exchange of rewards to effort, promises rewards for good performance, recognizes accomplishments (b) Management by Exception (active): Watches and searches for deviations from rules and standards, takes correct action (c) Management by Exception (passive): Intervenes only if standards are not decisions (d) Laissez-Faire: Abdicates responsibilities, Avoids making decisions"(Bass, 1990:22)[1]

Table 2. Variables of Transactional Leadership

\begin{tabular}{|r|l|}
\hline No & \multicolumn{1}{|c|}{$\begin{array}{c}\text { Variables of Transactional } \\
\text { Leadership }\end{array}$} \\
\hline 1. & Contingent Reward \\
\hline 2. & $\begin{array}{l}\text { Active Management by } \\
\text { Expectation }\end{array}$ \\
\hline 3. & Passive Avoidant Leadership \\
\hline
\end{tabular}

Contingent Reward is a dimension that describes a leader's managerial ability to clarify what the company will provide to employees if employee performance meets expectations. Active Management by Exception Is a dimension that describes a leader's managerial ability to focus on monitoring the implementation of tasks and problems that may arise while fixing problems to maintain performance. Passive Avoidant Leadership is a dimension that describes a leader's managerial ability to react after problems occur and problems have tended to become serious so that they can make wrong decisions.

\subsection{Transformasional Leadership}

(Wang and Berger 2010:4)[10] state that after the early 1980s, a fourth leadership theory emerged, namely transformational leadership, which has become the focal point of much research. According to this theory, people engage with one another and create a connection that leads to higher levels of motivation for both leaders and followers. (Spendlove 2007:411)[7] : "transformational leadership is based on a leader's charisma and intellectual inspiration".

(Von Eck and Verwey 2007: 42)[9]: "Contend that transformational leadership is based on developing an appealing vision of the future and motivating and inspiring followers to achieve organizational goals. Charismatic leadership is sometimes used interchangeably with transformational goals and is also based on motivation to attain goals".

(Bodla and Nawaz 2010:209)[3]: "which indicates that transformational leadership occurs when a leader is charismatic and motivates, inspires and stimulates his or her followers intellectually to achieve extraordinary goals".

(Von Eck and Verwey 2007: 43)[9]: "maintain that some of the skills associated with transformational leadership include the creation of a clear vision, communication skills, the ability to obtain buy-in for change, empowering people, flexibility and empathy".

Table 3. Variables of Transformational Leadership

\begin{tabular}{|c|c|}
\hline No & $\begin{array}{c}\text { Variables of Transactional } \\
\text { Leadership }\end{array}$ \\
\hline 1. & Charisma \\
\hline 2. & Intellectual Stimulation \\
\hline 3. & Individualized \\
\hline
\end{tabular}

Charisma is a dimension that describes a leader's managerial ability to inspire followers, provide energy and clear goals for employees as well as be a role model by applying ethical behavior to employees. Intellectual Stimulation is a dimension that describes the managerial ability of a leader to find out how his employees/subordinates solve problems while encouraging them to know what methods are used to solve the problems at hand. Individualized consideration is a dimension that describes a leader's managerial ability to understand the needs of each employee and try to provide their needs so that employees can use their potential to the fullest.

\section{METHODOLOGY}

The method used in this research is the descriptive method of quantitative data. The descriptive method is used to explain the results of the identification of the current conditions of leadership and service in the city of Pagar Alam.

\subsection{Research Instruments}

The data analysis method used in this research is a correlation. The correlation method is a research method that involves collecting data to 
determine whether there is a relationship and the degree of relationship between two or more variables. To measure the correlation between Transformational Leadership and service quality.

\subsection{Assessment Instrument Test}

\subsubsection{Validity Test}

The validity test is carried out by comparing the calculated $r$-value with the $r$ table value for the degree of freedom $(\mathrm{df})=\mathrm{n}-2$, in this case, $n$ is the number of samples. In the case of the validity test in this study, the number of samples $(n)=125$ each for the validity test on the service quality instrument and the multifactor leadership questionnaire instrument and the amount of df can be calculated as $125-2=123$ with df $=123$ and alpha $=0.1478$ (see $r$ table at $\mathrm{df}=123$ with onesided test). The assumptions used are if the $r$ count is greater than the $r$ table and the value is positive, then the item or statement, or indicator is said to be valid.

A validity test can be shown by using SPSS output. The magnitude of $\mathrm{N}$ for the trial is 125 respondents, $\mathrm{df}=123$ of 0.1478 . So a valid statement item has a calculated r-value greater than 0.1478. From the results of the SPSS output validity for the service quality questionnaire which consists of 22 questions and has 5 dimensions, the tangibles dimension consists of 4 questions, the reliability dimension consists of 5 questions, the responsiveness dimension consists of 4 questions, the assurance dimension consists of 4 questions and the empathy dimension consists of 5 questions. Meanwhile, the multifactor leadership questionnaire has 6 dimensions of 2 leadership styles where transformational leadership has 3 dimensions, namely the charisma dimension which consists of 12 questions, the intellectual stimulation dimension consists of 4 questions and the individualized consideration dimension consists of 4 questions while transactional leadership has 3 dimensions, namely the contingent reward dimension which consists of 4 questions, the active management by exception dimension consists of 4 questions and the passive avoidant leadership dimension consists of 8 questions. Of the 5 dimensions of the service quality questionnaire consisting of 22 questionnaire questions and the 6 dimensions of the multifactor leadership instrument questionnaire consisting of 36 questions, it can be stated that all question items are considered valid because the $r$ count is greater than 0.1478 . Thus the service quality questionnaire is appropriate to be given to 125 respondents, namely hotel guests and the multifactor leadership questionnaire is appropriate to be given to 125 respondents

\subsubsection{Reliability Test}

Testing the reliability of the five dimensions of service quality variables, for research respondent data, the value for the tangible dimension is 0.916, the assurance dimension is 0.948, the responsiveness dimension is 0.922 , the reliability dimension is 0.903 , and the empathy dimension is 0.955. Thus, it can be concluded that the five research variables are considered reliable because the obtained Cronbach alpha value is greater than 0.7, this agrees with (Nunally, 1978 (in jabnoun and rasasi, 2005:76)[6] "a coefficient alpha higher than 0.7 is considered to be good".

Testing the reliability of the three dimensions of the transformational leadership variable, for research respondent data, the value for the charisma dimension is 0.868 , the intellectual stimulation dimension is 0.763 , and the individualized consideration dimension is 0.706 . Thus, it can be concluded that the three research variables are considered reliable because the obtained Cronbach alpha value is greater than 0.7 , this agrees with (Nunally,1978 (in jabnoun and rasasi, 2005:76)[6] "a coefficient alpha higher than 0.7 is considered to be good".

Reliability testing of the three dimensions of the transactional leadership variable, for research respondent data, the value for the contingent reward dimension is 0.719 , the active management by exception dimension is 0.830 , and the passive avoidant leadership dimension is 0.865 . Thus, it can be concluded that the three research variables are considered reliable because the obtained Cronbach alpha value is greater than 0.7 , this agrees with (Nunally,1978 (in jabnoun and rasasi, 2005:76)[6] "a coefficient alpha higher than 0.7 is considered to be good". 


\section{RESULT}

\subsection{Quality of Service in the $F \& B$ Service Industry of Pagar Alam}

Overall Service Quality and the five dimensions of Service Quality have significant positive mean differences. The average value of all Service Quality variables and all Service Quality dimensions has a mean value > 4 . From these results, it can also be concluded that guests have a positive perception of the Service Quality provided by employees.

\subsection{Leadership Style In F\&B Service Industry Fences}

Transformational Leadership as a whole and the three dimensions of Transformational Leadership have significant positive mean values differences. The average value of all Transformational Leadership variables and all Transformational Leadership dimensions has a mean value of $>4$. While Transactional Leadership as a whole has a significant negative mean value difference. From table 4.4, it can be seen that only the Contingent Reward dimension (which describes the managerial ability of a leader to clarify what the company will provide to employees if the employee's performance meets company expectations) has a significant positive difference in the mean value.

From the results of the one-sample t-test above, it can be seen that the Intellectual Stimulation dimension has the highest mean value of 4.8860 . The results from table 4.4 show that all the Multifactor Leadership Questionnaire instruments have various answer variances, this is indicated by the P-Value $<0.05$. Meanwhile, the value of tc $>$ ta value for Transformational Leadership and all dimensions of Transformational Leadership while Transactional Leadership has a value of tc < ta value and all dimensions of Transactional Leadership except for the Contingent Reward dimension. From the results of the mean and $\mathrm{t}$ value, it can be concluded that Transformational Leadership has better characteristics than Transactional Leadership.

The application of the Transformational Leadership style to leadership is indicated by the one-sample t-test value of 3 transformational leadership style factors, namely Charisma, Intellectual Stimulation, and Individualized Consideration, which shows a test value of $>4$.

\subsection{Relationship between Leadership Style and Service Quality in Pagar Alam F\&B Service Industry}

SPSS output for the Pearson Correlation between the Service Quality dimensions and the Multifactor Leadership Questionnaire dimensions, there is an indication of a significant correlation relationship between all dimensions of the Multifactor Leadership Questionnaire and Service Quality except between the Empathy (Service Quality) dimension, where the relationship between the Empathy dimension and the Charisma dimension and the Intellectual dimension Stimulation has a positive but not significant correlation. it is known that all dimensions of Service Quality have a positive and significant correlation with all dimensions of Transformational Leadership with the highest score found in the relationship between Individualized Consideration and Reliability $(0.504 * *)$.

It can be concluded that all Service Quality dimensions do not have a strong relationship with the Transformational Leadership and Transactional Leadership dimensions. it is proven that from the two dimensions, no dimension has a very strong significant relationship (>0.7). In table 4.5 above, it can also be concluded from the Transactional Leadership dimension that only Contingent Rewards have a significant positive relationship to all Service Quality dimensions, while Active Management by Exception and Passive Avoidant Leadership has a significant negative relationship to all Service Quality dimensions.

\section{CONCLUSION}

1. Consumers have a positive perception of Service Quality in the F\&B Service industry in Pagar Alam. The mean result of One-Sample Statistics Service Quality shows a test value > 4 against 5 dimensions of SERVQUAL, namely Tangibles (4.9294), Assurance (4.9488), Responsiveness (5.1366), Reliability 
(5.4150), and Empathy (5.3104). With PValue $<0.005$

2. The Transformational Leadership Style has better characteristics than the Transactional Leadership Style in the F\&B Service industry in Pagar Alam. The mean result of the One-Sample Statistics Multifactor Leadership Questionnaire shows a test value of $>4$ on 3 dimensions of Transformational Leadership, namely Charisma (4.8055), Intellectual Stimulation (4.8860), Individualized Consideration (4.7160). Contingent Reward (4.6000) is the only type of leadership from Transformational Leadership that has a t-test value $>4$ with a $\mathrm{P}-$ Value value $<0.005$.

3. Transformational Leadership Style and Transactional Leadership Style have a significant relationship with Service Quality. The results of the Pearson Correlation show that all Service Quality dimensions correlate with the Multifactor Leadership Questionnaire, but the Empathy (Service Quality) dimension does not have a significant relationship with the Charisma and Intellectual Stimulation (Multifactor Leadership Questionnaire) dimensions.

Suggestion:

1. F\&B Service industry players in Pagar Alam must maintain the quality of their services as a strong factor in the eyes of guests.

2. F\&B Service industry players in Pagar Alam should continue to use the Transformational Leadership Style. Because the application of transformational leadership style has a positive significant relationship to performance objectivity in this case seen from Service Quality.

3. So that employees who work in the F\&B Service industry in Pagar Alam who carry out Service Quality can find out whether the performance carried out is by expectations and has been carried out well or not, the employee needs to be evaluated. Therefore, the role of the Department of Human Resources is as a determinant in making decisions and policies for developing human resources and establishing a conducive organizational climate to be able to provide objective assessments of employees who have done the work.

\section{AUTHOR'S CONTRIBUTION}

Samuel Hamonangan: Performed research, lead author, co-analyzed data. Pelliyezer Karo Karo: corresponding author, analyzed data, performed research. Zulkifli Harahap: co-authors, supervised site survey.

\section{ACKNOWLEDGMENTS}

Special thanks to fast food restauran Pagar Alam government and restaurant in are of Pagar Alam city.

\section{REFERENCES}

[1] Bass, B. M. Bass and Stogdill's handbook of leadership: Theory, research, and managerial applications. New York: Free Press, 1990a.

[2] Bass, B.M and Avolio, B. "Improving Organizational effectiveness through Transformational Leadership", Sage, thousand Oaks, CA, 1994.

[3] Bodla, M.A. \& Nawaz, M.M. "Comparative study of full range leadership model among faculty members in public and private sector higher education institutes and universities". International Journal of Business and Management, 5(4):208-214, 2010.

[4] Karo, P. K., \& Hamonangan, S. (2021). Analisis Strategi Pemasaran Restoran Menghadapi Masa Pandemi Covid 19 Di Kota Pagar Alam. Jurnal Sains Sosio Humaniora, 5(1), 396-408.

[4] Kotler, P. Marketing management: the millennium edition. Upper Saddle River, NJ: Prentice-Hall, 2000.

[5] Lau, P.M., Akbar, K. \& Gun Fie, D.Y. Service quality: a study of the luxury hotels 
in Malaysia. The Journal of American Academy of Business, 7(2):46-55, 2005.

[6] Nunally, J.C, "Psychometric Theory", McGraw-Hill, New York, NY, 1978.

[7] Spendlove, M. "Competencies for effective leadership in higher education". International Journal of Educational Management, 21(5):407-417. 2007.

[8] Van Schalkwyk, R.D. "The Impact of Leadership Practices on Service Quality in Private Higher Education in South Africa", 2011.

[9] Von Eck, C. \& Verwey, A. Change dynamics and related leadership competencies. Journal of Human Resource Management, 5(2):42-50, 2007.

[10] Wang, V.C.X. \& Berger, J. Critica analysis of leadership needed in higher education. International Forum of Teaching and Studies, 6(2):3-12, 2010.

[11] Wilson, A., Zeithaml, V.A., Bitner, J. \& Gremler, D. Services marketing. Maidenhead, Berkshire: McGraw-Hill, 2008. 